\title{
PENINGKATAN AKTIVITAS BELAJAR SISWA PADA MATA PELAJARAN EKONOMI MELALUI METODE PEMBELAJARAN KOOPERATIF MODEL JIGSAW PADA SISWA KELAS X IIS 2 SMA NEGERI 1 SITIUNG KABUPATEN DHARMASRAYA TAHUN AJARAN 2015/2016
}

\author{
Kaharudin \\ Guru SMA Negeri 1 Sitiung \\ kaharudin0231@gmail.com
}

\begin{abstract}
The purpose of this study was to determine whether student learning activities in economic learning could be improved by applying the Jigsaw Model of Cooperative Learning Method. This study involved students of class X IIS 2 at SMA N 1 Sitiung 2015/2016 in Academic Year and one economics teacher as an observer. This study consisted of two cycles, each cycle consisting of three meetings by applying the Jigsaw Model of Cooperative Learning Method. The results in the first cycle have not shown significant activity, so the second cycle continued. In the second cycle there were $85 \%$ of students who had been able to meet the assessment measure indicators. Based on the results of this study, researcher suggests other economics teachers to use appropriate learning methods such as this Jigsaw Method, learning becomes more fun and obtains satisfying results.
\end{abstract}

Keywords: learning activities, economic, cooperative learning, jigsaw model

\begin{abstract}
Abstrak
Tujuan penelitian ini adalah mengetahui apakah aktivitas belajar siswa dalam pembelajaran Ekonomi dapat ditingkatkan dengan menerapkan metode pembelajaran kooperatif tipe Jigsaw. Penelitian ini melibatkan siswa kelas X IIS 2 SMAN 1 Sitiung tahun ajaran 2015/2016 dan seorang guru pengamat. Penelitian ini terdiri dari dua siklus, setiap siklus terdiri dari tiga pertemuan dengan menerapkan metode pembelajaran kooperatif model Jigsaw. Hasil pada siklus I belum menunjukkan aktivitas yang berarti, sehingga dilanjutkan siklus II. Pada siklus II terdapat $85 \%$ siswa yang sudah mampu memenuhi indikator ukuran penilaian. Berdasarkan hasil penelitian ini, peneliti menyarankan kepada guru Ekonomi lainnya untuk menggunakan metode Jigsaw ini, pembelajaran menjadi lebih menyenangkan dan memperoleh hasil yang memuas.

Kata Kunici: aktivitas belajar, ekonomi, koperatif learning, model jigsaw
\end{abstract}

\section{PENDAHULUAN}

Permasalahan dalam penelitian ini adalah peserta didik yang kurang termotivasi dalam beraktivitas belajar pada mata pelajaran ekonomi. Aktivitas tersebut meliputi kegiatan seperti menyiapkan peta-peta konsep yang mudah dimengerti siswa, menampilkan bahan ajar dengan power point diiringi dengan gambar-gambar sebagai motivasi, memperbanyak membahas soal-soal dan memberikan latihan dikelas maupun dirumah, namun hasilnya tetap jauh dari yang diharapkan, oleh sebab itu sangat perlulah kiranya metode-metode mengajar 
yang mungkin dapat meningkatkan aktivitas belajar siswa Berdasarkan data pra observasi yang peneliti lakukan ternyata siswa kelas X IIS 2 terlihat bahwa aktivitas mereka sangat rendah dalam belajar ekonomi, mereka lebih banyak diam dan pasif. Oleh sebab itu penulis menggunakan model pembelajaran Jigsaw untuk meningkatkan aktivitas belajar siswa.

\section{Pembelajaran Ekonomi}

Ekonomi merupakan ilmu tentang prilaku dan tindakan manusia untuk memenuhi kebutuhan hidupnya yang bervariasi dan berkembang dengan sumber daya yang ada melalui pilihan-pilihan kegiatan produksi, konsumsi dan distribusi. Belajar ilmu ekonomi itu ternyata menyenangkan karena ekonomi adalah diri kita sendiri. Banyak sekali keputusan yang kita buat didasarkan pada prinsip-prinsip ekonomi, jelas terlihat saat kita dihadapkan pada beberapa pilihan, keputusan akhir dari pilihan dipengaruhi oleh bekerjanya prinsip-prinsip ekonomi, Dengan kata lain dipengaruhi oleh pertimbangan ekonomi. Sangat menarik karena belajar ekonomi erat kaitannya dengan peristiwa sehari-hari yang terjadi pada diri dan lingkungan disekitar kita, dengan belajar ekonomi siswa mampu merekam fenomena ekonomi yang ada disekitarnya dan mengambil manfaat untuk kehidupannya yang lebih baik. (Slamet Sukamto dkk, 2007)

\section{Pengertian Aktivitas Belajar}

Aktivitas belajar adalah suatu tindakan yang melibatkan fisik maupun psikis pada diri seseorang untuk mencapai suatu tujuan yaitu tujuan belajar menurut Mulyono (2009: 12) aktivitas siswa merupakan kegiatan atau perilaku yang terjadi selama proses belajar mengajar yaitu kegiatan yang mengarah pada proses belajar seperti bertanya, mengajukan pendapat, mengerjakan tugas, dapat menjawab pertanyaan guru dan bisa bekerjasama dengan siswa lain, serta tanggung jawab terhadap tugas yang diberikan. Belajar dikatakan berhasil mestilah melalui berbagai macam aktivitas, baik aktivitas fisik maupun psikis.

\section{Pembelajaran Model Jigsaw}

Dalam model pembelajaran Jigsaw siswa melakukan suatu kegiatan belajar dengan cara bekerjasama dengan siswa lain untuk mencapai suatu tujuan. Siswasiswa ini bekerjasama untuk menyelesaikan tugas kooperatifnya dalam: a) belajar dan menjadi ahli dalam subtopik bagiannya; b) merencanakan bagaimana mengajarkan subtopik bagiannya kepada anggota kelompoknya semula. Setelah itu, siswa tersebut kembali lagi ke kelompok masing-masing sebagai "ahli" dalam subtopiknya dan mengajarkan informasi penting dalam subtopik tersebut kepada temanya. Ahli dalam subtopik lainnya juga bertindak serupa. Sehingga seluruh siswa bertanggung jawab untuk menunjukkan penguasaannya terhadap seluruh materi yang ditugaskan oleh guru. Dengan demikian, setiap siswa dalam kelompok harus menguasai topik secara keseluruhan.

Menurut Rusman (2010) Langkah-langkah model jigsaw sebagai berikut:

1. Siswa dikelompokkan dengan anggota \pm 4 orang

2. Tiap orang dalam tim diberi materi dan tugas yang berbeda

3. Anggota dari tim yang berbeda dengan penugasan yang sama membentuk kelompok baru (kelompok ahli).

4. Setelah kelompok ahli berdiskusi,tiap anggota kembali ke kelompok asal dan menjelaskan kepada anggota kelompok tentang subbab yang mereka kuasai. 
5. Tiap tim ahli mempresentasikan hasil diskusinya

6. Guru memberi evaluasi

7. Penutup

\section{METODOLOGI PENELITIAN}

Penelitian tindakan kelas ini dilaksanakan di SMA Negeri 1 Sitiung Kabupaten Dharmasraya, dari Januari 2016 sampai dengan Mei 2016. Peneliti melaksanakan penelitian dalam waktu dua siklus, masing-masing siklus terdiri dari tiga kali pertemuan dikelas dengan menggunakan model Jigsaw. Subjek penelitian tindakan kelas ini adalah siswa kelas X IIS 2 SMA Negeri 1 Sitiung kabupaten Dharmasraya, yang berjumlah 32 orang terdiri dari laki-laki sebanyak 15 orang dan perempuan 17 orang. Siklus 1 dilaksanakan 3 kali pertemuan. Pertemuan 1 pada tanggal 11 Februari 2016, pertemuan 2 pada tanggal 18 Februari 2016 dan pertemuan 3 dilaksanakan pada tanggal 4 Maret 2016. Siklus 2 dilaksanakan 3 kali pertemuan, pertemuan 1 pada tanggal 11 maret 2016, pertemuan 2 pada tanggal 18 Maret 2016 dan pertemuan 3 dilaksanakan pada tanggal 15 April 2016.

\section{Prosedur Penelitian}

Rencana tindakan yaitu gambaran tentang langkah riil yang akan dilakukan dalam tindakan. Ada 4 tahapan yang dilalui dalam penelitian tindakan ini yaitu: perencanaan, plaksanaan, pengamatan, dan refleksi. Adapun model untuk masingmasing siklus sebagai berikut:

\section{Perencanaan}

Perencanaan disusun berdasarkan masalah dan hipotesis tindakan yang diuji secara empiris sehingga perubahan yang diharapkan dapat mengidentifikasi aspek dari hasil proses belajar mengajar.

\section{Pelaksanaan Tindakan}

Semua kegiatan yang direncanakan dapat dilaksanakan dalam pembelajaran. Guru selaku peneliti langsung melaksanakan tindakan sesuai dengan apa yang sudah direncanakan dalam tahap perencanaan penelitian.Peneliti dalam melaksanakan tindakan penelitian menggunakan metode pembelajaran kooperatif model Jigsaw sebagai bentuk perbaikan pembelajaran.

\section{Pengamatan}

Pengamatan dilakukan oleh peneliti itu sendiri dan dibantu oleh observer dengan mengisi intrumen yang telah disediakan. Dalam tahap pengamatan, observer akan menggunakan intrumen yaitu berupa lembar observasi untuk memotret proses pembelajaran yang menggunakan model Jigsaw selama proses penelitian. Observer mengisi lembar observasi dengan jujur dan objektif tanpa adanya intervensi dari peneliti.

\section{Refleksi}

Refleksi akan dilakukan oleh peneliti bersama observer untuk melihat proses pembelajaran ekonomi dikelas melalui model Jigsaw. Dalam tahap ini peneliti dan observer membahas tindakan selanjutnya apakah peneliti perlu untuk melakukan perencanaan ulang atau tidak. Kemajuan aktifitas siswa dapat dilihat dalam bentuk persentase, nilai yang diperoleh dilakukan pengolahan data sebagai berikut: Siswa dikatakan aktif secara klasikal jika sudah mencapai $75 \%$. Data aktifitas belajar yang diperoleh dikatakan meningkat apabila aktifitas belajar yang diperoleh dari siklus kedua lebih tinggi dari aktifitas belajar siklus pertama. 


\section{HASIL PENELITIAN DAN PEMBAHASAN}

\section{Hasil Penelitian}

a. Pra observasi

Pelaksanaan pra observasi menunjukan hasil bahwa dari 32 siswa kelas $\mathrm{X}$ IIS 2 hanya empat orang yang aktif dalam proses pembelajaran ekonomi, keaktifan nya sangat menonjol sekali dibandingkan 28 orang siswa yang lainnya.Data ini bisa dikatakan bahwa dalam proses pembelajaran ekonomi dikelas X IIS 2 hanya terdapat 12,5\% siswa yang aktif belajar, sedangkan $87,5 \%$ siswa tidak aktif dalam proses pembelajaran.

\section{Siklus Pertama}

\section{1) Perencanaan}

i. Dalam merencanakan guru memberikan motivasi, apersepsi.

ii. Guru menyampaikan SK, KD,judul materi dan tujuan pembelajaran.

iii. Guru mengkaitkan pembelajaran sebelumnya dengan pembelajaran yang akan dilaksanakan.

iv. Guru menyampaikan strategi pembelajaran dengan metode jigsaw.

v. Siswa dibagi dalam kelompok atau tim kecil terdiri dari empat orang yang dinamakan kelompok kooparatif.

vi. Tiap orang dalam tim diberi materi dan tugas yang berbeda setiap soal diberi nomor.

vii. Anggota dari masing-masing kelompok kooparatif berkumpul dengan anggota kooparatif lain dengan nomor soal yang sama,kemudian membentuk kelompok ahli terdiri dari 8 orang.

viii. Setelah kelompok ahli berdiskusi, tiap anggota kembali kekelompok asal dan menjelaskan kepada anggota kelompok tentang materi yang mereka kuasai.

ix. Tiap tim ahli mempresentasikan hasil diskusinya

x. Guru mengamati aktivitas siswa.

xi. Guru membuat catatan pribadi pada jurnal.

2) Pelaksanaan

Pelaksanaan pada siklus pertama penelitian tindakan kelas, guru melakukan tindakan sesuai tahap - tahap dalam perencanaan. Sedangkan observer mengamati berlangsungnya kegiatan pembelajaran dengsn metode jigsaw.

3) Hasil

\section{a) Pertemuan pertama}

Siklus pertama dilaksanakan tiga kali pertemuan, dan dari lembaran observasi peneliti dapat mengemukakan bahwa pada siklus pertama pertemuan pertama didapatkan data sebagai berikut, dari delapan kelompok diskusi terdapat satu kelompok yang bergerak aktif, namun masih belum percaya diri untuk bertanya ataupun menjawab pertanyaan, jadi pada siklus pertama pertemuan satu dominan $16 \%$ kelompok yang melaksanakan semua indikator pengukuran keaktifan siswa.

Dari lembaran observasi dapat dilihat bahwa kelompok GR.Terry terlihat tidak aktif baru dalam batas mencatat hal-hal penting, kelompok Hendry Fayol mencoba berlomba mengumpulkan tugas meskipun hasilnya belum maksimal, sedangkan indikator yang lain masih belum mampu dilaksanakan, kelompok 
Horold Koontz belum sepenuhnya menguasai bahan ajar juga tidak terlihat aktif dalam diskusi kelompok apalagi untuk bertanya ataupun menjawab pertanyaan guru, namun kelompok ini telah mencatat hal-hal penting dan lebih awal mengumpulkan tugas meskipun belum sempurna. kelompok Hasibuan hanya baru mencatat hal-hal penting sedangkan indikator yang lain belum terlaksana sebagaimana halnya kelompok Sondang P.Siagian, hal ini sepertinya disebabkan karena kurang percaya diri untuk tampil didepan teman-temannya.

Kelompok enam yang bernama kelompok Andrew menunjukan persentase yang paling tinggi yaitu mencapai 50\%, kelompok ini kelihatan lebih aktif, berusaha untuk menguasai materi, aktif dalam diskusi begitu juga mencatat halhal penting, namun masih belum mampu menjawab pertanyaan guru ataupun bertanya saat diberi kesempatan bertanya oleh guru. Kelompok E.P Strong mau berinisiatif menjawab pertanyaan guru namun belum sesuai dengan jawaban yang seharusnya, kelompok C.O Donnel dari enam indikator yang diamati baru mampu mencatat hal-hal penting. Jadi pada siklus satu pertemuan satu ini hanya satu kelompok yang aktif dalam belajar ekonomi dengan menerapkan model jigsaw meskipun belum sepenuhnya.

\section{b) Pertemuan kedua}

Pada hasil pertemuan kedua terlihat bahwa sudah ada dua kelompok yang mengalami kemajuan meskipun baru 50\% yaitu kelompok GR Terry yang telah menguasai bahan ajar, berani mengacungkan tangan untuk bertanya juga mencatat hal-hal penting sebagai pertinggal dan kelompok Horold Koontz yang juga berusaha menguasai bahan ajar, aktif dalam diskusi juga mencatat hal-hal penting meskipun masih ragu-ragu untuk bertanya dan tak percaya diri untuk menjawab pertanyaan guru. Sedangkan kelompok yang lain belum ada peningkatan aktivitas yang signifikan.

Jadi pada siklus satu pertemuan kedua ini hanya dua kelompok yang mulai aktif dalam belajar ekonomi dengan menerapkan model jigsaw meskipun belum sepenuhnya.

\section{c) Pertemuan ketiga}

Pada siklus pertama pertemuan ketiga beberapa kelompok sudah mulai terlihat kemajuannya salah satu kelompok sudah mencapai 66\%, dua kelompok yang lain mencapai 50\% yaitu kelompok GR.Terry dan kelompok Sondang P Siagian, sedangkan yang lainnya mencapai 33\%, dan satu kelompok masih $16 \%$ yaitu E.P Strong. Jadi pada siklus satu pertemuan ketiga ini terdapat satu kelompok yang sudah dinyatakan aktif, dua kelompok yang mulai aktif dalam belajar ekonomi dengan menerapkan model jigsaw meskipun belum sepenuhnya. Perubahan aktivitas siswa pada siklus pertama dengan tiga kali pertemuan terlihat pada grafik dibawah ini. 


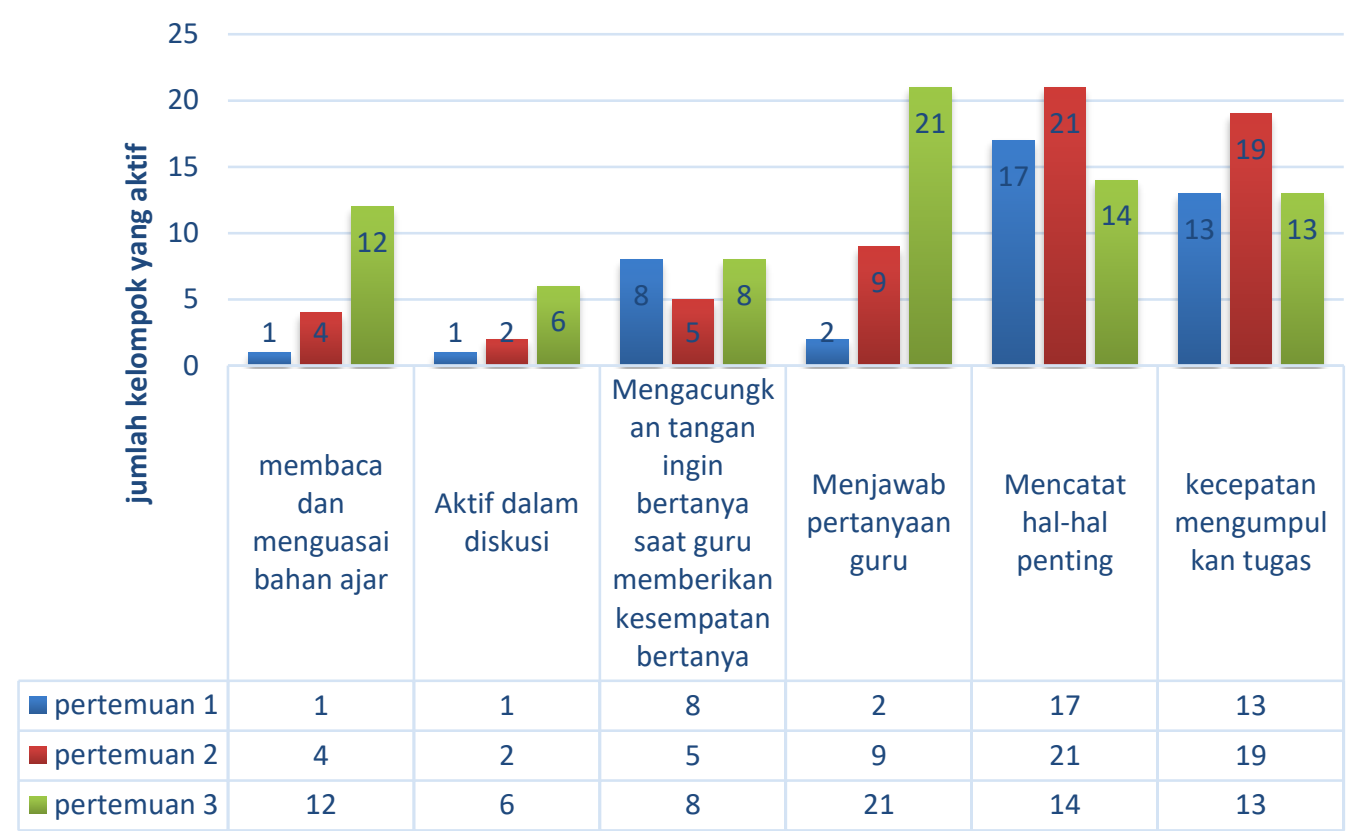

Gambar 1. Aktivitas belajar siswa pada siklus 1 untuk pertemuan 1, 2, dan 3

4) Refleksi

Dalam siklus pertama setelah dilakukan analisa terhadap hasil observasi, juga catatan harian peneliti selaku guru bidang studi, wawancara singkat terhadap siswa serta diskusi dengan kolaborator maka didapatlah data bahwa pada siklus pertama siswa masih belum mampu mencapai keenam indikator aktivitas belajar. Oleh sebab itu peneliti dan kolaborator bersepakat melakukan suatu tindakan yang dapat memicu keaktifan siswa dalam bekerja kelompok dengan memberikan reward, dimana kelompok yang paling sedikit bertanya, tidak dapat menjawab pertanyaan atau kurang tepat menjawab pertanyaan, dan kelompok yang tidak serius dalam presentasi akan disuruh bernyanyi didepan kelas, oleh sebab itu siswa diminta mempersiapkan satu lagu masing-masing agar proses reward lancar.

\section{Siklus Kedua}

1) Perencanaan

Peneliti merencanakan kegiatan pembelajaran pada siklus kedua seperti perencanaan pada siklus pertama.

2) Pelaksanaan

Pelaksanaan pada siklus kedua penelitian tindakan kelas, guru melakukan beberapa tindakan yang sama pada siklus pertama dan di perbaiki setelah adanya kegiatan refleksi. Penambahan kegiatan di siklus kedua adalah pemberian reward bagi kelompok yang tergolong aktif.

3) Hasil

a) Pertemuan Pertama

1) Siklus kedua dilaksanakan tiga kali pertemuan, dan dari lembaran observasi peneliti dapat mengemukakan bahwa pada siklus kedua pertemuan pertama 
sudah terlihat kemajuan secara signifikan, dimana dari delapan kelompok diskusi terdapat tiga kelompok yang bergerak aktif yaitu mencapai $66 \%$, dua kelompok mencapai 50\% dan satu kelompok masih dalam rentangan $33 \%$. Pada siklus 2 pertemuan satu ini kelompok GR.Terry sudah mencapai 66\%, dari enam indikator kelompok ini sudah sudah menguasai bahan ajar dengan baik, sudah semua aktif dalam diskusi terutama dalam bertanya, namun masih belum percaya diri untuk menjawab pertanyaan. Kelompok Hendry Fayol pada sudah ada kemajuan pada empat indikator namun untuk keaktifan dalam diskusi dan mengacungkan tangan untuk bertanya.

Kelompok Horold Koontz juga sudah mencapai 66\%, kelompok ini sudah terlihat aktif dalam diskusi kelompok namun kalah cepat dalam mengumpulkan tugas dan belum dapat giliran untuk bertanya. Kelompok Hasibuan baru mencapai $50 \%$, dan belum aktif dalam diskusi juga belum berpacu untuk bertanya saat diberi kesempatan oleh guru. Kelompok Sondang P.Siagian aktivitas mencapai 50\% masih terlihat kurang aktif dalam diskusi dan dalam menguasai bahan ajar, namun dua orang dari kelompok ini sudah aktif bertanya meskipun terlambat dari kelompok lain dalam mengumpulkan tugas. Kelompok Andrew masih terlihat pasif ini barangkali disebabkan karna ada saja anggota kelompok yang tidak hadir disaat diskusi dilaksanakan.

\section{b) Pertemuan Kedua}

Pada Siklus kedua pertemuan kedua didapatkan data sebagai berikut, dari delapan kelompok diskusi sudah terdapat dua kelompok yang mencapai 83\%, dua kelompok $66 \%$ dan dua kelompok 50\%. Pada siklus kedua pertemuan kedua ini sudah nampak kemajuan yang signifikan. Pada siklus dua pertemuan kedua ini $50 \%$ kelompok sudah terlihat sangat aktif persentase keaktifan mencapai $83 \%$, sedangkan 50\% lagi mulai aktif meskipun baru sebahagian indikator yang sudah tercapai, seperti kelompok GR.Terry tujuh dari delapan indikator telah tercapai dengan baik namun masih ragu-ragu menjawab pertanyaan guru, setelah ditanya siswa seakan takut salah.

\section{c) Pertemuan ketiga}

Pada pertemuan ketiga dalam siklus kedua ini persentase keberhasilan sudah sangat terlihat, terdapat dua kelompok yang telah mencapai $100 \%$ dan hanya satu kelompok yang tingkat keaktifannya 50\%. Kelompok yang telah melaksanakan ke enam indikator dengan baik adalah kelompok GR.Terry dan kelompok Horold Koont, sedangkan kelompok Hendry Fayol, Kelompok Hasibuan dan kelompok Andrew telah memenuhi tujuh dari delapan indikator. Perubahan aktivitas siswa pada siklus kedua dengan tiga kali pertemuan terlihat pada grafik dibawah ini. 


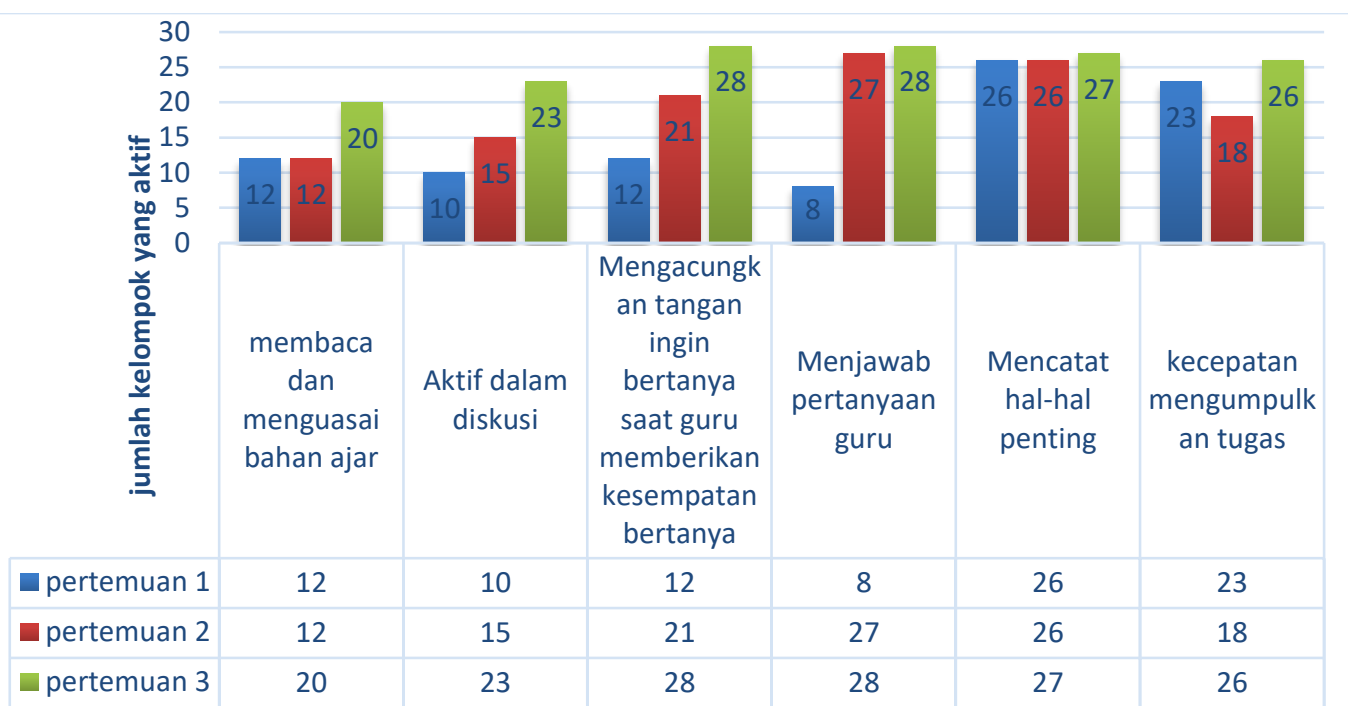

Gambar 2. Aktivitas belajar siswa pada siklus 2 untuk peremuan 1, 2, dan 3. 4) Refleksi

Pada siklus kedua pertemuan pertama belum terlihat perubahan aktivitas secara signifikan, hanya beberapa kelompok yang mampu memenuhi keenam indikator namun itupun belum sempurna. maka peneliti lebih menekankan lagi pemberian reward sebagai perangsang keaktifan siswa. Sehingga pada pertemuan kedua ketercapaian indikator mencapai $85 \%$ untuk beberapa kelompok bahkan pada pertemuan ketiga ada beberapa kelompok telah mencapai $100 \%$. Jadi setelah siklus kedua siswa sepertinya sudah merasakan manfaat belajar berkelompok, peneliti memperoleh informasi dari beberapa siswa mereka mengatakan bahwa belajar berkelompok seperti model jigsaw sangat mudah memahami materi pelajaran karena siswa dituntut bersama-sama dalam kelompoknya dan saling bantu menguasai materi pelajaran. Perbandingan keaktifan siswa pada siklus pertama dengan siklus kedua dapat dilihat pada gambar dibawah ini.

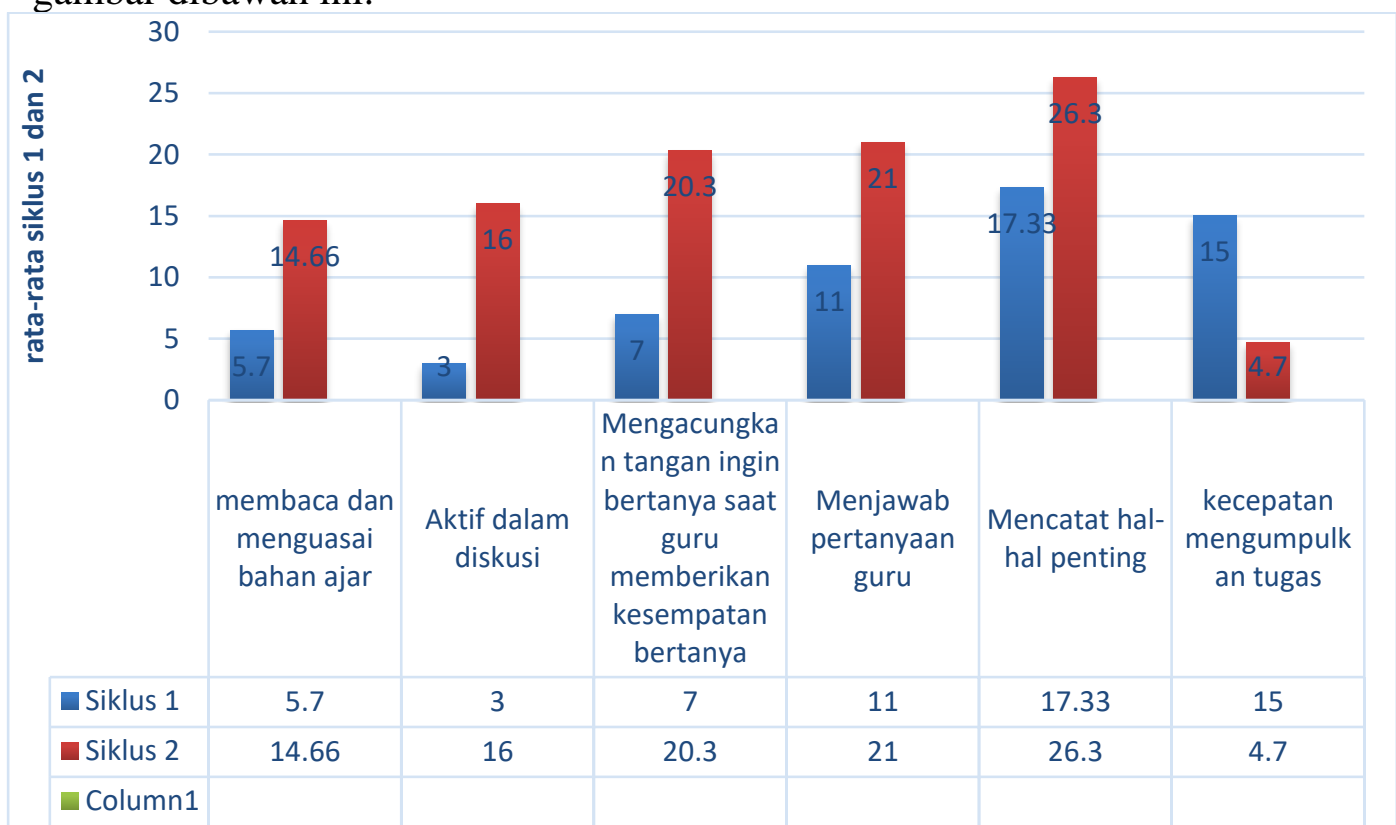

Gambar 3. Perbandingan aktivitas belajar siswa pada siklus 1dan siklus 2 


\section{PEMBAHASAN}

Pada siklus pertama pertemuan pertama terlihat bahwa ada peningkatan aktivitas belajar ekonomi. Akan tetapi pada pertemuan pertama ini hanya satu kelompok yang memenuhi tiga dari enam indikator yang peneliti jadikan tolak ukur, sedangkan siswa lain melakukan aktivitas lain seperti bercerita dengan teman, menggambar, melamun dan ada juga yang mengerjakan tugas mata pelajaran lain. Pada pertemuan kedua terjadi peningkatan.

Pada pertemuan kedua terlihat kemajuan aktivitas kelompok meskipun ragu-ragu untuk bertanya ataupun menjawab pertanyaan, hal ini disebabkan karena kurang percaya diri dan takut salah. Pada pertemuan ketiga terdapat tiga kelompok yang terlihat sangat aktif, berpacu untuk lebih dulu mendapat kesempatan apakah itu bertanya ataupun menjawab pertanyaan. Sedangkan kelompok lain mulai termotivasi dengan ikut mengacungkan tangan untuk bertanya ataupun menjawab pertanyaan namun acungan tangan seperti raguragu tidak terlalu tinggi. Pada siklus kedua pertemuan pertama terlihat dari delapan kelompok ada empat kelompok yang menunjukan keaktifannya, meskipun satu dari enam indikator yang diamati masih belum tercapai secara sempurna.

Jadi selama dua siklus berlangsung dengan enam kali pertemuan ternyata dengan menggunakan model jigsaw dalam pembelajaran ekonomi siswa dapat meningkat aktivitas belajarnya, karena model ini menuntut siswa untuk bekerjasama dalam kelompok dan saling membantu menguasai materi yang diberikan guru.

\section{PENUTUP}

\section{Simpulan}

Berdasarkan hasil penelitian peningkatan aktivitas belajar ekonomi siswa kelas X IIS 2 maka dapat disimpulkan bahwa, Melalui penerapan Metode Kooperatif Model Jigsaw dalam pembelajaran ekonomi menunjukan adanya peningkatan dalam aktivitas belajar siswa dikelas X IPS 2 Semester 2 Tahun Pelajaran 2015/2016.

\section{Saran}

Berdasarkan pengalaman dalam penelitian tindakan kelas ini maka peneliti menyarankan guru sebaiknya mempersiapkan model pembelajaran yang menarik, merancang skenario pembelajaran yang dapat menciptakan kelas yang interaktif dan komunikatif dan memilih bahan teks yang familiar dengan siswa.

\section{DAFTAR PUSTAKA}

A.M. Sardiman.2001. Interaksi Dan Motivasi Belajar Mengajar. PT Raja Grafindo Persada: Jakarta

Arikunto,S. 2009. Prosedur Penelitian Suatu Pendekatan Praktik. Rineka Cipta: Jakarta

Dimyati, dan Mudjiono. 2010. Belajar dan Pembelajaran.Rineka Cipta: Jakarta

Dzaki, M. Faiq. 2009. Aktivitas Belajar Pada Model Pembelajaran Kooperatif [internet]. [diacu 2017 Jan 3]. Tersedia dari: http:penelitiantindakankelas.blogspot.co.id/2009/03/aktivitas-belajar-padamodel.html 
Mulyono. 2009. Pendidikan Bagi Anak Berkesulitan Belajar. Rineka Cipta: Jakarta.

Rusman. 2010. Model-model Pembelajaran Mengembangkan Profesionaliisme Guru. PT Raja Grafindo Persada: Jakarta

Slamet Sukamto. dkk 2007. Ekonomi SMA/MA kelas X. Yudhistira; Jakarta

Slameto. 2003. Belajar dan Faktor-faktor yang Mempengaruhinya. Rineka Cipta: Jakarta

Slavin, Robert E. 2005. Cooperative Learning: Teori, Riset Dan Praktik. Nusa Media: Bandung.

Sudjana. 1996. Teknik Analisis Regresi Dan Korelasi. Tarsito: Bandung 